\title{
Thermoelectric Ceramics Based on the Layered Cobaltates of Bismuth and Alkaline-Earth Metals
}

\author{
Andrei Klyndyuk ${ }^{*}$, Ekaterina Chizhova, Natalie Krasutskaya \\ Department of Physical and Colloid Chemistry, Belarusian State Technological University, Belarus Republic
}

Copyright@2017 by authors, all rights reserved. Authors agree that this article remains permanently open access under the terms of the Creative Commons Attribution License 4.0 International License

\begin{abstract}
Using solid-state reactions method the ceramic samples of $(\mathrm{Bi}, \mathrm{Pb})_{2} \mathrm{Ba}_{2}(\mathrm{Co}, M)_{2} \mathrm{O}_{y}$, $(\mathrm{Bi}, \mathrm{Pb})_{2} \mathrm{Sr}_{2}(\mathrm{Co}, M)_{1.8} \mathrm{O}_{y}$, and $(\mathrm{Bi}, \mathrm{Pb})_{2} \mathrm{Ca}_{2}(\mathrm{Co}, M)_{1.7} \mathrm{O}_{y}(M=$ $\mathrm{Mn}, \mathrm{Zn})$ solid solutions had been prepared, their lattice constants had been determined and their thermal expansion, electrical conductivity and thermo-EMF had been measured, and their power factor had been calculated. Effect of the bismuth substitution by lead and cobalt substitution by manganese and zinc in the layered cobaltates of bismuth and alkaline-earth metals (AEM) on the crystal structure and physicochemical and functional properties of their derivatives was analyzed. It was found that cobaltates studied are $p$-type conductors, which linear thermal expansion coefficient (LTEC) values varied within (9.6813.2) $\cdot 10^{-6} \mathrm{~K}^{-1}$. Power factor values for the samples studied unmonotonously changed when temperature increased and at $1000 \mathrm{~K}$ were maximal for $\mathrm{Bi}_{2} \mathrm{Ba}_{2} \mathrm{Co}_{2} \mathrm{O}_{y}, \mathrm{Bi}_{2} \mathrm{Sr}_{2} \mathrm{Co}_{1.7} \mathrm{Mn}_{0.1} \mathrm{O}_{y}$, and $\mathrm{Bi}_{2} \mathrm{Ca}_{2} \mathrm{Co}_{1.7} \mathrm{O}_{y}$ compounds $-12.1,10.1$, and $10.6 \mu \mathrm{W} /\left(\mathrm{m} \cdot \mathrm{K}^{2}\right)$ respectively.
\end{abstract}

Keywords Layered Bismuth and Alkaline-Earth Metals Cobaltates, Thermoelectrics, Thermal Expansion, Electrical Conductivity, Thermo-EMF, Power Factor

\section{Introduction}

Heat evolved into environment during working of factories and transport can be effectively and directly converted into electrical energy in devices called thermoelectrogenerators (TEGs) [1]. To produce TEGs one needs to use materials named thermoelectrics, which must possess high values of electrical conductivity and thermo-EMF and low thermal conductivity. Traditional thermoelectrics such as $\mathrm{Bi}_{2} \mathrm{Te}_{3}$, or PbTe, cannot be used at high temperatures as they can melt or oxidize when working under air. Oxide thermoelectrics can work at high temperatures for a long time, so, they were studied very intensively last year [2-4].

For making high-temperature thermoelectrogenerators one needs both $n$-type and $p$-type thermoelectric materials. Manganites $\left(\mathrm{CaMnO}_{3}\right)[2,5]$, titanates $\left(\mathrm{TiO}_{2}, \mathrm{SrTiO}_{3}\right)[2,6]$, or plumbates $\left((\mathrm{Ba}, \mathrm{Sr}) \mathrm{PbO}_{3}\right)[2,7,8]$ are prospective $n$-type thermoelectrics, but layered cobaltates $\left(\mathrm{Na}_{x} \mathrm{CoO}_{2}[2,9,10]\right.$, $\mathrm{Ca}_{3} \mathrm{Co}_{4} \mathrm{O}_{9+\delta}[2,11,12], \mathrm{Bi}_{2} \mathrm{Ba}_{2} \mathrm{Co}_{2} \mathrm{O}_{y}$ [13], $\mathrm{Bi}_{2} \mathrm{Sr}_{2} \mathrm{Co}_{1.8} \mathrm{O}_{y}$ [14], $\mathrm{Bi}_{2} \mathrm{Ca}_{2} \mathrm{Co}_{1.7} \mathrm{O}_{y}$ [15-17]) are prospective p-type thermoelectrics.

Layered cobaltates of bismuth and alkaline-earth metal $\left(\mathrm{Bi}_{2} \mathrm{Ba}_{2} \mathrm{Co}_{2} \mathrm{O}_{y}, \mathrm{Bi}_{2} \mathrm{Sr}_{2} \mathrm{Co}_{1.8} \mathrm{O}_{y}, \mathrm{Bi}_{2} \mathrm{Ca}_{2} \mathrm{Co}_{1.7} \mathrm{O}_{y}\right)$ belong to the so-called misfit-layered phases, which structure consists of stacked $\left[\mathrm{CoO}_{2}\right]$ layers (structure type of $\mathrm{CdI}_{2}$ ) and $\left[\mathrm{Bi}_{2} \mathrm{M}_{2} \mathrm{O}_{4}\right]$ $(M=\mathrm{Ca}, \mathrm{Sr}, \mathrm{Ba})$ (structure type of $\mathrm{NaCl}$ ), where $a, c$, and $\beta$ of both of layers are identical, but $b$ parameters differ [13-15]. These complex oxides possess high electrical conductivity due to high concentration of charge carriers ("holes") in conducting $\left[\mathrm{CoO}_{2}\right]$ layers, high values Seebeck's coefficient because cobalt ions in their structure are in different charge $\left(\mathrm{Co}^{3+}\right.$, and $\left.\mathrm{Co}^{4+}\right)$ and spin states (high-spin state, intermediate-spin state, and low-spin state), and have low thermal conductivity due to strong anisotropy and mismatch of their crystal structure in $b$ direction.

To improve functional (thermoelectric) properties of ceramic materials based on these layered compounds one can use solution method synthesis instead of traditional solid-state reactions method [15, 17], special methods of thermal treatment and sintering of ceramics [17], as well as chemical substitution of different ions in their structure [6, $11,12,14]$.

The aim of this work is to study the effect of partial substitution of bismuth by lead and of cobalt by manganese or zinc on the crystal structure and physicochemical properties of solid solutions based on the layered cobaltates of bismuth and alkaline-earth metals $\left(\mathrm{Bi}_{2} \mathrm{Ba}_{2} \mathrm{Co}_{2} \mathrm{O}_{y}\right.$, $\left.\mathrm{Bi}_{2} \mathrm{Sr}_{2} \mathrm{Co}_{1.8} \mathrm{O}_{y}, \mathrm{Bi}_{2} \mathrm{Ca}_{2} \mathrm{Co}_{1.7} \mathrm{O}_{y}\right)$.

\section{Materials and Methods}

The ceramic samples of the layered cobaltates of bismuth and alkaline-earth metals were prepared using solid-state reactions method from $\mathrm{Bi}_{2} \mathrm{O}_{3}$ (pure grade), $\mathrm{BaCO}_{3}$ (pure grade), $\mathrm{SrCO}_{3}$ (pure grade), $\mathrm{PbO}$ (pure for analysis grade), 
$\mathrm{Mn}_{2} \mathrm{O}_{3}$ (super pure grade), $\mathrm{Co}_{3} \mathrm{O}_{4}$ (pure grade), and $\mathrm{ZnO}$ (pure grade) taken in appropriate stoichiometric compositions in air at different conditions (see Table 1).

Table 1. Temperature and time of synthesis and sintering of ceramics

\begin{tabular}{|c|c|c|}
\hline Compound & Synthesis & Sintering \\
\hline $\mathrm{Bi}_{2} \mathrm{Ca}_{2} \mathrm{Co}_{1,7} \mathrm{O}_{\mathrm{y}}$ & $1073 \mathrm{~K} / 12 \mathrm{~h}$ & $1133 \mathrm{~K} / 12 \mathrm{~h}$ \\
\hline $\mathrm{Bi}_{1,6} \mathrm{~Pb}_{0,4} \mathrm{Ca}_{2} \mathrm{Co}_{1,7} \mathrm{O}_{\mathrm{y}}$ & $1073 \mathrm{~K} / 12 \mathrm{~h}$ & $1073 \mathrm{~K} / 12 \mathrm{~h}$ \\
\hline $\mathrm{Bi}_{2} \mathrm{Ca}_{2} \mathrm{Co}_{1,6} \mathrm{Mn}_{0,1} \mathrm{O}_{\mathrm{y}}$ & $1073 \mathrm{~K} / 12 \mathrm{~h}$ & $1133 \mathrm{~K} / 12 \mathrm{~h}$ \\
\hline $\mathrm{Bi}_{2} \mathrm{Ca}_{2} \mathrm{Co}_{1,6} \mathrm{Zn}_{0,1} \mathrm{O}_{\mathrm{y}}$ & $1073 \mathrm{~K} / 12 \mathrm{~h}$ & $1133 \mathrm{~K} / 12 \mathrm{~h}$ \\
\hline $\mathrm{Bi}_{2} \mathrm{Sr}_{2} \mathrm{Co}_{1,8} \mathrm{O}_{\mathrm{y}}$ & $1073 \mathrm{~K} / 12 \mathrm{~h}$ & $1113 \mathrm{~K} / 12 \mathrm{~h}$ \\
\hline $\mathrm{Bi}_{1,6} \mathrm{~Pb}_{0,4} \mathrm{Sr}_{2} \mathrm{Co}_{1,8} \mathrm{O}_{\mathrm{y}}$ & $1073 \mathrm{~K} / 12 \mathrm{~h}$ & $1073 \mathrm{~K} / 12 \mathrm{~h}$ \\
\hline $\mathrm{Bi}_{2} \mathrm{Sr}_{2} \mathrm{Co}_{1,7} \mathrm{Mn}_{0,1} \mathrm{O}_{\mathrm{y}}$ & $1073 \mathrm{~K} / 12 \mathrm{~h}$ & $1113 \mathrm{~K} / 12 \mathrm{~h}$ \\
\hline $\mathrm{Bi}_{2} \mathrm{Sr}_{2} \mathrm{Co}_{1,7} \mathrm{Zn}_{0,1} \mathrm{O}_{\mathrm{y}}$ & $1073 \mathrm{~K} / 12 \mathrm{~h}$ & $1113 \mathrm{~K} / 12 \mathrm{~h}$ \\
\hline $\mathrm{Bi}_{2} \mathrm{Ba}_{2} \mathrm{Co}_{2} \mathrm{O}_{\mathrm{y}}$ & $1053 \mathrm{~K} / 12 \mathrm{~h}$ & $1053 \mathrm{~K} / 12 \mathrm{~h}$ \\
\hline $\mathrm{Bi}_{1,6} \mathrm{~Pb}_{0.4} \mathrm{Ba}_{2} \mathrm{Co}_{2} \mathrm{O}_{\mathrm{y}}$ & $1073 \mathrm{~K} / 12 \mathrm{~h}$ & $1073 \mathrm{~K} / 12 \mathrm{~h}$ \\
\hline $\mathrm{Bi}_{2} \mathrm{Ba}_{2} \mathrm{Co}_{1,9} \mathrm{Mn}_{0,1} \mathrm{O}_{\mathrm{y}}$ & $1073 \mathrm{~K} / 12 \mathrm{~h}$ & $1073 \mathrm{~K} / 12 \mathrm{~h}$ \\
\hline $\mathrm{Bi}_{2} \mathrm{Ba}_{2} \mathrm{Co}_{1,9} \mathrm{Zn}_{0,1} \mathrm{O}_{\mathrm{y}}$ & $1073 \mathrm{~K} / 12 \mathrm{~h}$ & $1073 \mathrm{~K} / 12 \mathrm{~h}$ \\
\hline
\end{tabular}

The values of the sintering temperatures of the ceramics were chosen in such a way as to avoid its melting and were based on the results of our preliminary experiments.

Identification of the samples and determination of their lattice constants was performed using $\mathrm{X}$-ray diffraction analysis (XRD) (Bruker D8 XRD Advance diffractometer, $\mathrm{CuK}_{\alpha}-$ radiation, Ni filter). The apparent density $(\rho)$ of the samples was calculated using their mass and geometrical dimensions.

Thermal expansion, electrical conductivity and thermo-EMF coefficient of the samples were investigated in air within 300-1100 K temperature interval by methods described in $[8,10,12]$. Linear thermal expansion coefficient (LTEC, $\alpha$ ) values of the oxides studied were calculated from the linear parts of the $\Delta l / l_{0}=f(T)$ depencences. Values of power factor of the ceramics were calculated using formula $P$ $=S^{2} \cdot \sigma$.

\section{Results and Their Discussion}

As can be seen from the Figure 1, all the samples prepared, were, within XRD accuracy, monophase (excluding $\quad \mathrm{Bi}_{2} \mathrm{Sr}_{2} \mathrm{Co}_{1.7} \mathrm{Zn}_{0.1} \mathrm{O}_{y}, \quad \mathrm{Bi}_{1.6} \mathrm{~Pb}_{0.4} \mathrm{Sr}_{2} \mathrm{Co}_{1.8} \mathrm{O}_{y}$ compounds, on which diffractograms, in addition to the reflexes of main phase - layered bismuth-strontium cobaltate - the reflexes of impurity phase were observed), and their structure corresponded to the structure of layered cobaltate of bismuth and AEM [13-15]. Partial substitution of bismuth by lead and of cobalt by manganese or zinc in $\mathrm{Bi}_{2} M_{2} \mathrm{Co}_{x} \mathrm{O}_{y}(\mathrm{M}=\mathrm{Ca}$, Sr, Ba) cobaltates did not affect the form of diffractograms and had only led to the small shifts of the peaks positions to the smaller or larger angles (Figure 1), so such substitution does not affect the crystal structure of the samples but only changed their lattice constants. On the diffractograms of all samples the $00 \mathrm{l}$ peaks were most pronounced, so we can conclude that ceramics were partially textured (its grains were aligned mainly in direction of $c$ axis).
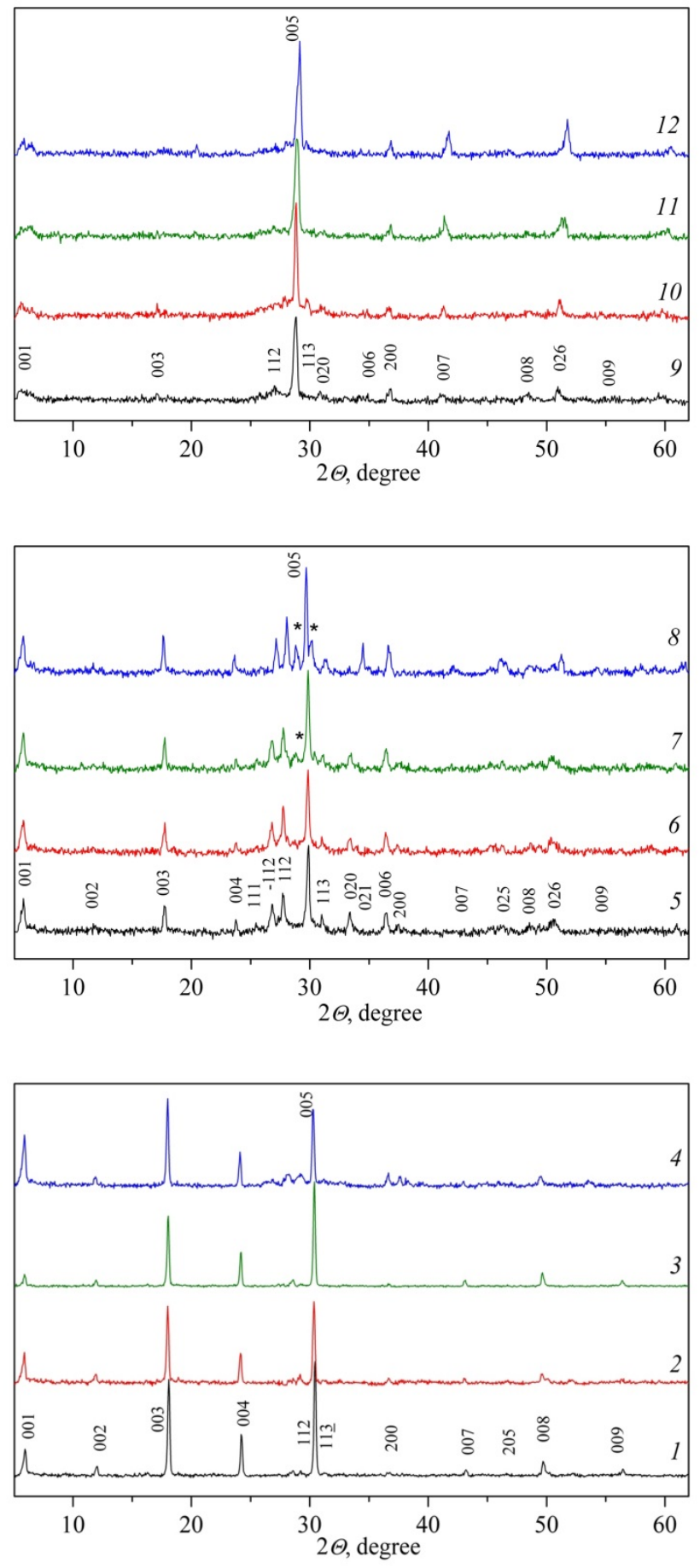

Figure 1. X-ray powder diffractograms ( $\mathrm{CuK}_{\alpha}$-radiation) of bismuth and AEM layered cobaltates powdered samples: $1-\mathrm{Bi}_{2} \mathrm{Ca}_{2} \mathrm{Co}_{1.7} \mathrm{O}_{y}, 2$ $\mathrm{Bi}_{2} \mathrm{Ca}_{2} \mathrm{Co}_{1.6} \mathrm{Mn}_{0.1} \mathrm{O}_{y}, 3-\mathrm{Bi}_{2} \mathrm{Ca}_{2} \mathrm{Co}_{1.6} \mathrm{Zn}_{0.1} \mathrm{O}_{y}, 4-\mathrm{Bi}_{1.6} \mathrm{~Pb}_{0.4} \mathrm{Ca}_{2} \mathrm{Co}_{1.7} \mathrm{O}_{y .} 5-$ $\mathrm{Bi}_{2} \mathrm{Sr}_{2} \mathrm{Co}_{1.8} \mathrm{O}_{y}, 6-\mathrm{Bi}_{2} \mathrm{Sr}_{2} \mathrm{Co}_{1.7} \mathrm{Mn}_{0.1} \mathrm{O}_{y}, 7-\mathrm{Bi}_{2} \mathrm{Sr}_{2} \mathrm{Co}_{1.7} \mathrm{Zn}_{0.1} \mathrm{O}_{y}, 8-$ $\mathrm{Bi}_{1.6} \mathrm{~Pb}_{0.4} \mathrm{Sr}_{2} \mathrm{Co}_{1.8} \mathrm{O}_{y}, 9-\mathrm{Bi}_{2} \mathrm{Ba}_{2} \mathrm{Co}_{2} \mathrm{O}_{y}, 10-\mathrm{Bi}_{2} \mathrm{Ba}_{2} \mathrm{Co}_{1.9} \mathrm{Mn}_{0.1} \mathrm{O}_{y}, 11-$ $\mathrm{Bi}_{2} \mathrm{Ba}_{2} \mathrm{Co}_{1.9} \mathrm{Zn}_{0.1} \mathrm{O}_{y}, 12-\mathrm{Bi}_{1.6} \mathrm{~Pb}_{0.4} \mathrm{Ba}_{2} \mathrm{Co}_{2} \mathrm{O}_{y}$. Symbol * depicts the impurity phase 
Table 2. Syngony, lattice constants ( $a, b, c, \beta, V)$, apparent density $(\rho)$, and linear thermal expansion coefficient $(\alpha)$ of the bismuth and AEM layered cobaltates

\begin{tabular}{|c|c|c|c|c|c|c|c|c|}
\hline Compound & Syngony & $a, \AA$ & $b, \AA$ & $c, \AA$ & $\beta,{ }^{\circ}$ & $V, \AA^{3}$ & $\rho, g / \mathrm{cm}^{3}$ & $\alpha \cdot 10^{6}, \mathrm{~K}^{-1}$ \\
\hline $\mathrm{Bi}_{2} \mathrm{Ca}_{2} \mathrm{Co}_{1,7} \mathrm{O}_{\mathrm{y}}$ & $\mathrm{M}$ & 4.894 & 4.765 & 14.69 & 93.74 & 341.8 & 5.00 & 9.68 \\
\hline $\mathrm{Bi}_{1,6} \mathrm{~Pb}_{0,4} \mathrm{Ca}_{2} \mathrm{Co}_{1,7} \mathrm{O}_{\mathrm{y}}$ & $\mathrm{M}$ & 4.910 & 4.779 & 14.74 & 93.59 & 345.3 & 4.78 & 11.7 \\
\hline $\mathrm{Bi}_{2} \mathrm{Ca}_{2} \mathrm{Co}_{1,6} \mathrm{Mn}_{0,1} \mathrm{O}_{\mathrm{y}}$ & $\mathrm{M}$ & 4.912 & 4.812 & 14.74 & 93.96 & 347.5 & 4.98 & 10.6 \\
\hline $\mathrm{Bi}_{2} \mathrm{Ca}_{2} \mathrm{Co}_{1,6} \mathrm{Zn}_{0,1} \mathrm{O}_{\mathrm{y}}$ & $\mathrm{M}$ & 4.915 & 4.774 & 14.71 & 93.37 & 344.5 & 4.19 & 11.4 \\
\hline $\mathrm{Bi}_{2} \mathrm{Sr}_{2} \mathrm{Co}_{1,8} \mathrm{O}_{\mathrm{y}}$ & $\mathrm{M}$ & 4.824 & 5.367 & 14.98 & 91.29 & 387.8 & 4.54 & 11.5 \\
\hline $\mathrm{Bi}_{1,6} \mathrm{~Pb}_{0,4} \mathrm{Sr}_{2} \mathrm{Co}_{1,8} \mathrm{O}_{\mathrm{y}}$ & $\mathrm{M}$ & 4.877 & 5.275 & 15.04 & 93.10 & 386.4 & 4.49 & 12.4 \\
\hline $\mathrm{Bi}_{2} \mathrm{Sr}_{2} \mathrm{Co}_{1,7} \mathrm{Mn}_{0,1} \mathrm{O}_{\mathrm{y}}$ & $\mathrm{M}$ & 4.811 & 5.354 & 14.96 & 91.24 & 385.3 & 4.32 & 12.2 \\
\hline $\mathrm{Bi}_{2} \mathrm{Sr}_{2} \mathrm{Co}_{1,7} \mathrm{Zn}_{0,1} \mathrm{O}_{\mathrm{y}}$ & $\mathrm{M}$ & 4.821 & 5.347 & 14.95 & 91.76 & 385.2 & 4.80 & 12.6 \\
\hline $\mathrm{Bi}_{2} \mathrm{Ba}_{2} \mathrm{Co}_{2} \mathrm{O}_{\mathrm{y}}$ & $\mathrm{O}$ & 4.886 & 5.799 & 15.43 & - & 437.3 & 5.14 & 11.3 \\
\hline $\mathrm{Bi}_{1.6} \mathrm{~Pb}_{0.4} \mathrm{Ba}_{2} \mathrm{Co}_{2} \mathrm{O}_{\mathrm{y}}$ & $\mathrm{O}$ & 4.874 & 5.820 & 15.17 & - & 430.5 & 5.66 & 13.2 \\
\hline $\mathrm{Bi}_{2} \mathrm{Ba}_{2} \mathrm{Co}_{1,9} \mathrm{Mn}_{0,1} \mathrm{O}_{\mathrm{y}}$ & $\mathrm{O}$ & 4.887 & 5.776 & 15.45 & - & 436.1 & 5.28 & 12.4 \\
\hline $\mathrm{Bi}_{2} \mathrm{Ba}_{2} \mathrm{Co}_{1,9} \mathrm{Zn}_{0,1} \mathrm{O}_{\mathrm{y}}$ & $\mathrm{O}$ & 4.866 & 5.773 & 15.32 & - & 430.5 & 5.18 & 12.3 \\
\hline
\end{tabular}
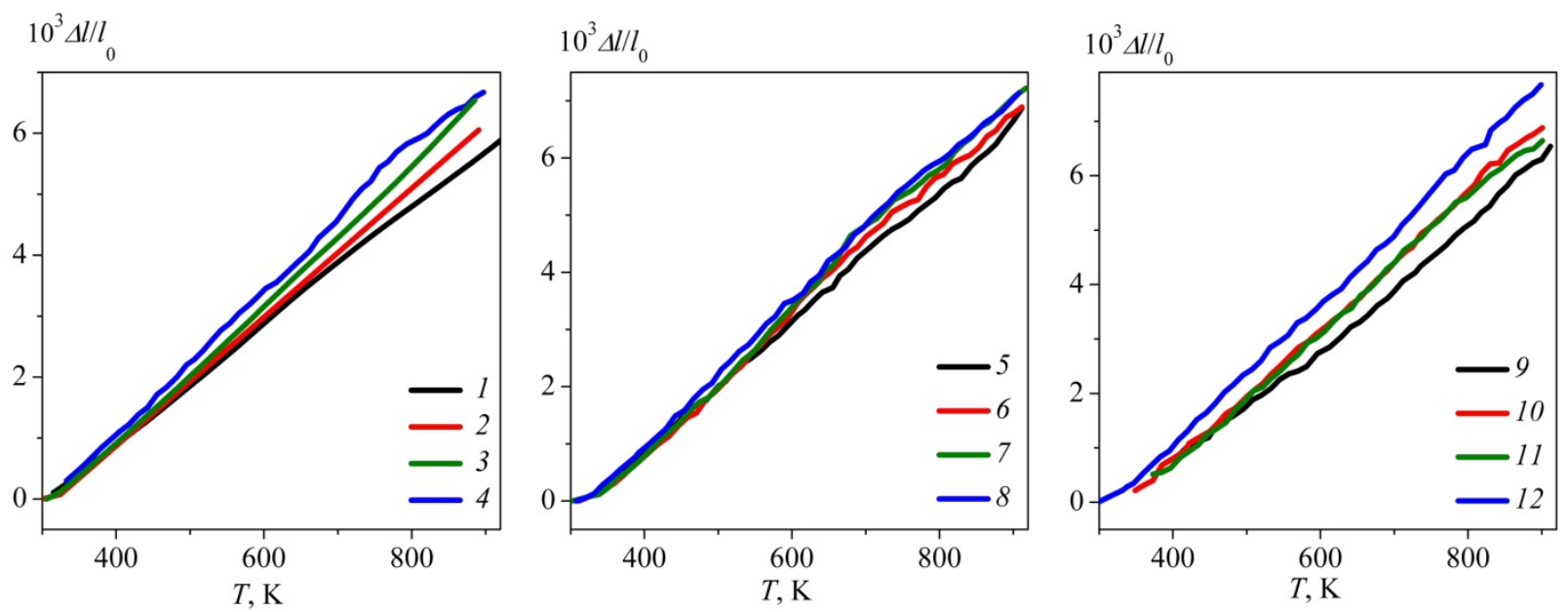

Figure 2. Temperature dependences of the relative elongation $\left(\Delta l / l_{0}\right)$ of the sintered ceramics of bismuth and $A E M$ layered cobaltates: $1-\mathrm{Bi}_{2} \mathrm{Ca}_{2} \mathrm{Co}_{1.7} \mathrm{O}_{y}$, $2-\mathrm{Bi}_{2} \mathrm{Ca}_{2} \mathrm{Co}_{1.6} \mathrm{Mn}_{0.1} \mathrm{O}_{y}, 3-\mathrm{Bi}_{2} \mathrm{Ca}_{2} \mathrm{Co}_{1.6} \mathrm{Zn}_{0.1} \mathrm{O}_{y}, 4-\mathrm{Bi}_{1.6} \mathrm{~Pb}_{0.4} \mathrm{Ca}_{2} \mathrm{Co}_{1.7} \mathrm{O}_{y} .5-\mathrm{Bi}_{2} \mathrm{Sr}_{2} \mathrm{Co}_{1.8} \mathrm{O}_{y}, 6-\mathrm{Bi}_{2} \mathrm{Sr}_{2} \mathrm{Co}_{1.7} \mathrm{Mn}_{0.1} \mathrm{O}_{y}, 7-\mathrm{Bi}_{2} \mathrm{Sr}_{2} \mathrm{Co}_{1.7} \mathrm{Zn}_{0.1} \mathrm{O}_{y}, 8-\mathrm{Bi}_{1.6} \mathrm{~Pb}_{0.4} \mathrm{Sr}_{2} \mathrm{Co}_{1.8} \mathrm{O}_{y}, 9$ $-\mathrm{Bi}_{2} \mathrm{Ba}_{2} \mathrm{Co}_{2} \mathrm{O}_{y}, 10-\mathrm{Bi}_{2} \mathrm{Ba}_{2} \mathrm{Co}_{1.9} \mathrm{Mn}_{0.1} \mathrm{O}_{y}, 11-\mathrm{Bi}_{2} \mathrm{Ba}_{2} \mathrm{Co}_{1.9} \mathrm{Zn}_{0.1} \mathrm{O}_{y}, 12-\mathrm{Bi}_{1.6} \mathrm{~Pb}_{0.4} \mathrm{Ba}_{2} \mathrm{Co}_{2} \mathrm{O}_{y}$.

The lattice constants of the samples studied are given in the Table 2. One can see that partial substitution in the $\mathrm{Bi}_{2} \mathrm{Ca}_{2} \mathrm{Co}_{1.7} \mathrm{O}_{y}$ of bismuth by lead and of cobalt by manganese or zinc results in the increasing of lattice constants of $\mathrm{Bi}_{1.6} \mathrm{~Pb}_{0.4} \mathrm{Ca}_{2} \mathrm{Co}_{1.7} \mathrm{O}_{\mathrm{y}}$ and $\mathrm{Bi}_{2} \mathrm{Ca}_{2} \mathrm{Co}_{1.6} M_{0.1} \mathrm{O}_{y}(M$ $=\mathrm{Mn}, \mathrm{Zn}$ ) solid solutions. In contrast, lattice constants of the solid solutions formed, decreased in the whole, at substitution of $\mathrm{Bi}$ by $\mathrm{Pb}$ and of $\mathrm{Ca}$ by $\mathrm{Mn}$ or $\mathrm{Zn}$ in $\mathrm{Bi}_{2} \mathrm{Ba}_{2} \mathrm{Co}_{2} \mathrm{O}_{y}$ and $\mathrm{Bi}_{2} \mathrm{Sr}_{2} \mathrm{Co}_{1.8} \mathrm{O}_{y}$ (see Table 2).

The lattice constants of parent phases $\left(\mathrm{Bi}_{2} \mathrm{Ba}_{2} \mathrm{Co}_{2} \mathrm{O}_{y}\right.$, $\mathrm{Bi}_{2} \mathrm{Sr}_{2} \mathrm{Co}_{1.8} \mathrm{O}_{y}, \mathrm{Bi}_{2} \mathrm{Ca}_{2} \mathrm{Co}_{1.7} \mathrm{O}_{y}$ ) calculated on the base of results obtained in this work are close to the literature data according to which for $\mathrm{Bi}_{2} \mathrm{Ba}_{2} \mathrm{Co}_{2} \mathrm{O}_{y} a=4.8842(7) \AA, b=$ 5.6398(8) $\AA, c=15.437(1) \AA$ [13], for $\mathrm{Bi}_{2} \mathrm{Sr}_{2} \mathrm{Co}_{1.8} \mathrm{O}_{y} a=$ $4.934 \AA, b=5.414 \AA, c=14.965 \AA$, and $\beta=93.41^{\circ}$ [14], and for $\mathrm{Bi}_{2} \mathrm{Ca}_{2} \mathrm{Co}_{1.7} \mathrm{O}_{y} a=4.9049(4) \AA, b=4.7135(7) \AA, c=$ 14.668(5) $\AA, \beta=93.32(1)^{\circ}[15], a=4.915(4) \AA, b=4.750(3)$ $\AA, c=14.676(4) \AA, \beta=93.46(4)^{\circ}[16]$.

Apparent density of the sintered ceramics varied within 4.19-5.68 g/ $\mathrm{cm}^{3}$ (Table 2) and in comparison with the parent phases were only larger for the $\mathrm{Bi}_{2} \mathrm{Sr}_{2} \mathrm{Co}_{1,7} \mathrm{Zn}_{0,1} \mathrm{O}_{\mathrm{y}}$,
$\mathrm{Bi}_{1.6} \mathrm{~Pb}_{0.4} \mathrm{Ba}_{2} \mathrm{Co}_{2} \mathrm{O}_{\mathrm{y}}, \quad \mathrm{Bi}_{2} \mathrm{Ba}_{2} \mathrm{Co}_{1,9} \mathrm{Mn}_{0,1} \mathrm{O}_{\mathrm{y}}, \quad$ and $\mathrm{Bi}_{2} \mathrm{Ba}_{2} \mathrm{Co}_{1,9} \mathrm{Zn}_{0,1} \mathrm{O}_{\mathrm{y}}$ solid solutions. So results of this work show that sinterability of $\mathrm{Bi}_{2} \mathrm{Ca}_{2} \mathrm{Co}_{1.7} \mathrm{O}_{y}$ and $\mathrm{Bi}_{2} \mathrm{Sr}_{2} \mathrm{Co}_{1.8} \mathrm{O}_{y}$ deteriorates, in the whole, at partial substitution in it of $\mathrm{Bi}$ or Co by other metals, but sinterability of $\mathrm{Bi}_{2} \mathrm{Ba}_{2} \mathrm{Co}_{2} \mathrm{O}_{y}$, in contrary, is improved at such substitution.

Temperature dependences of the relative elongation of all ceramic samples investigated were close to the linear (Figure 2); so, we can conclude that within temperature interval studied these compounds do not undergo any structural phase transitions. LTEC values of the $\mathrm{Bi}_{1.6} \mathrm{~Pb}_{0.4} \mathrm{Co}_{x} \mathrm{O}_{y}$ and $\mathrm{Bi}_{2} M_{2} \mathrm{Co}_{x-0.1} M_{0.1} \mathrm{O}_{y}(M=\mathrm{Mn}$, $\mathrm{Zn})$ solid solutions varied within (11.7-13.2) $10^{-6} \mathrm{~K}^{-1}$ and were essentially larger than for unsubstituted cobaltates $\mathrm{Bi}_{2} M_{2} \mathrm{Co}_{x} \mathrm{O}_{y}\left((11.7-13.2) \cdot 10^{-5} \mathrm{~K}^{-1}\right)$ (Table 2).

Obtained increasing of LTEC values of $\mathrm{Bi}_{2} \mathrm{M}_{2} \mathrm{Co}_{x} \mathrm{O}_{y}$ derivatives in comparison to the $\mathrm{Bi}_{2} M_{2} \mathrm{Co}_{x} \mathrm{O}_{y}$ base phases, by our opinion, is due to the increasing of anharmonicity degree of metal-oxygen vibrations in their structure at partial substitution of bismuth by lead or cobalt by manganese or zinc. 


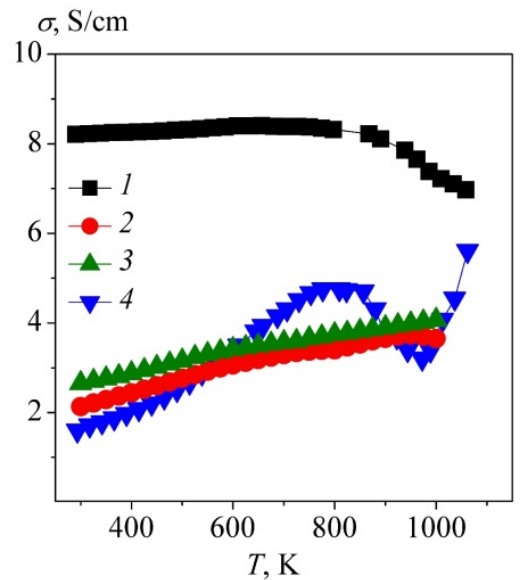

\section{$S, \mu \mathrm{V} / \mathrm{K}$}
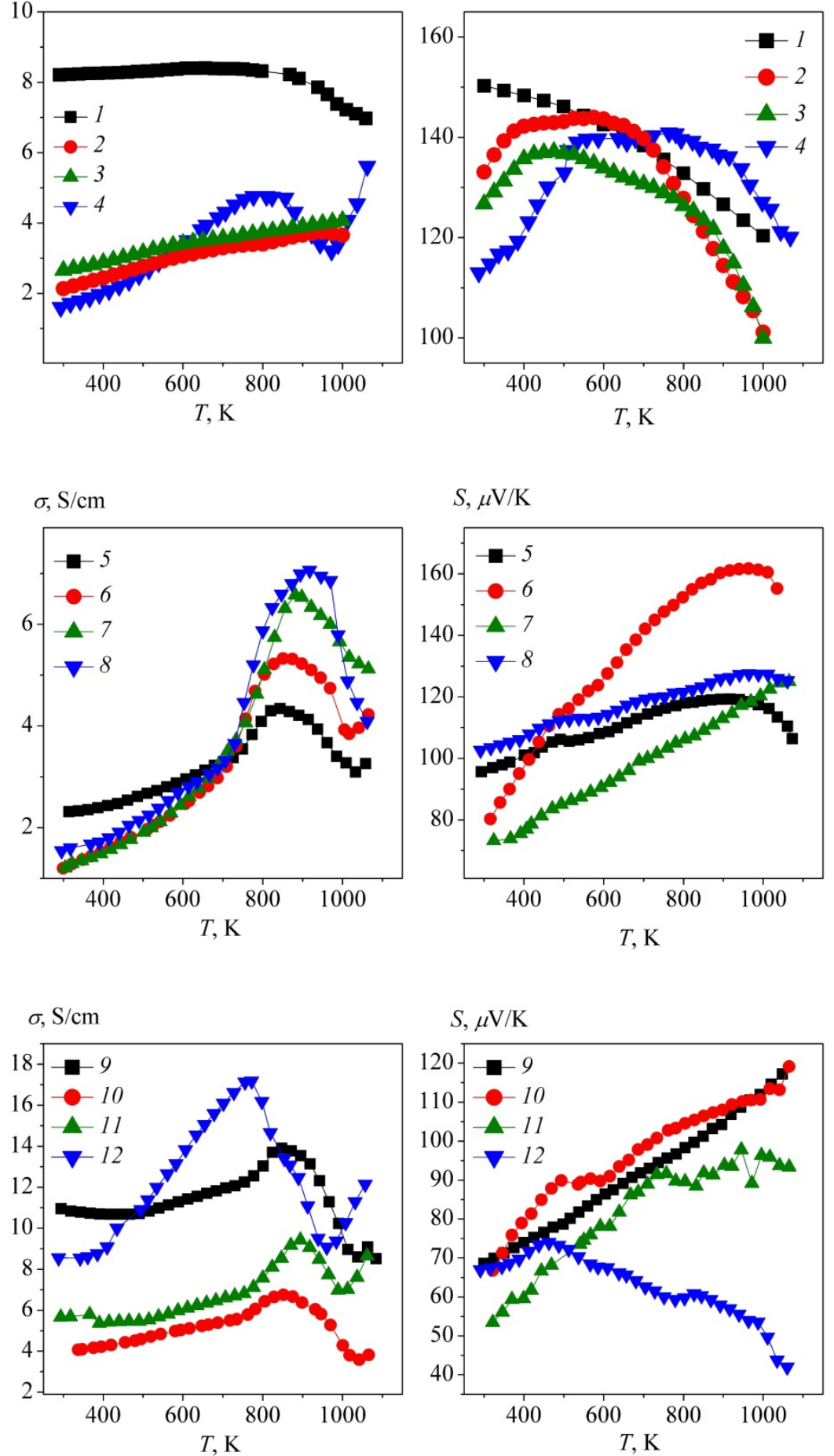

$S, \mu \mathrm{V} / \mathrm{K}$

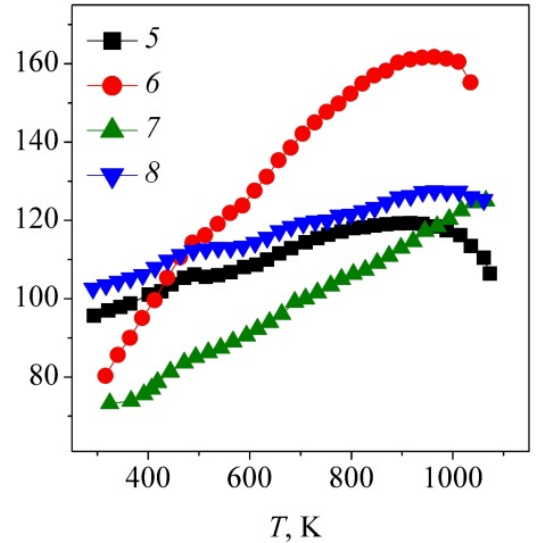

$S, \mu \mathrm{V} / \mathrm{K}$
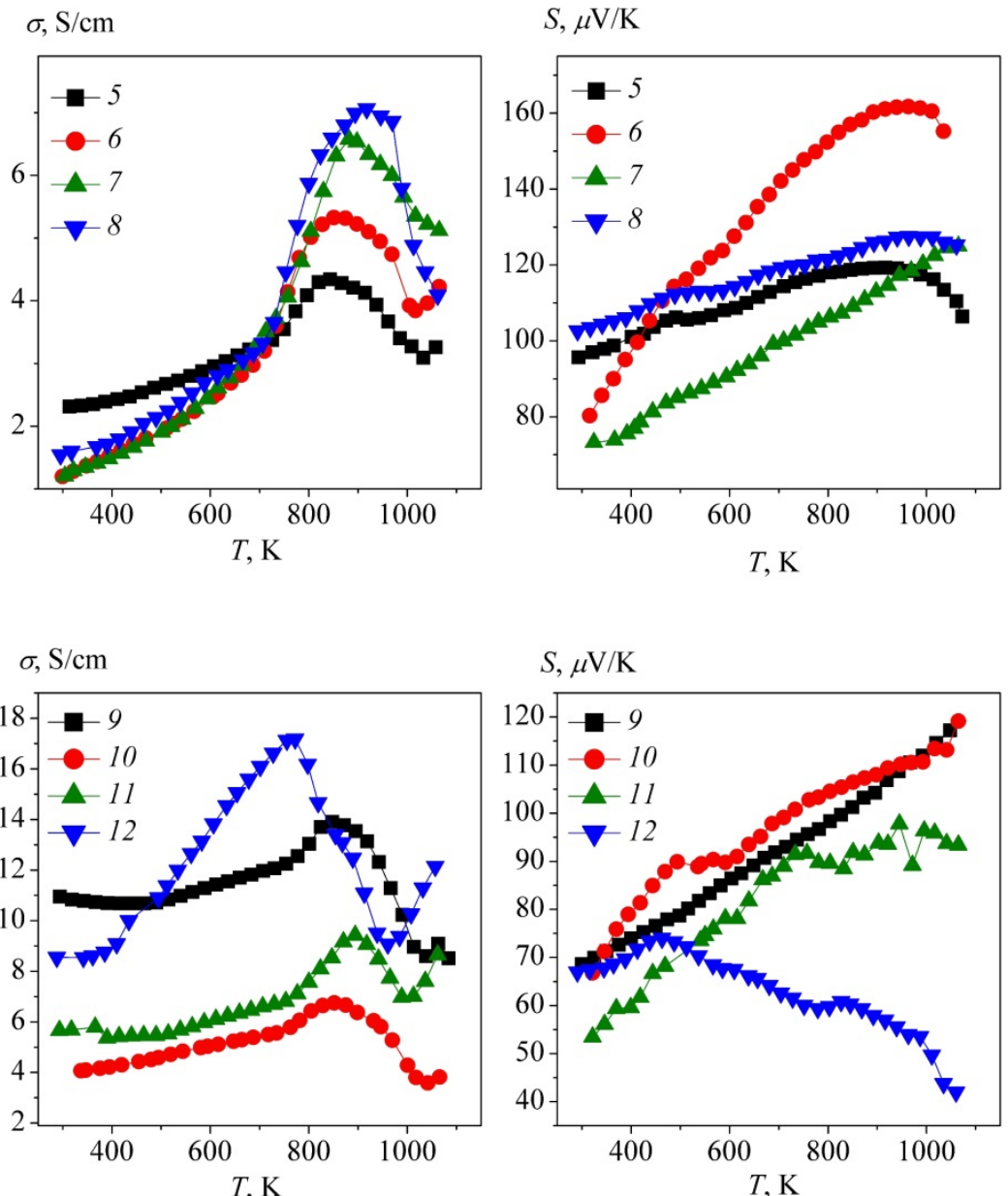
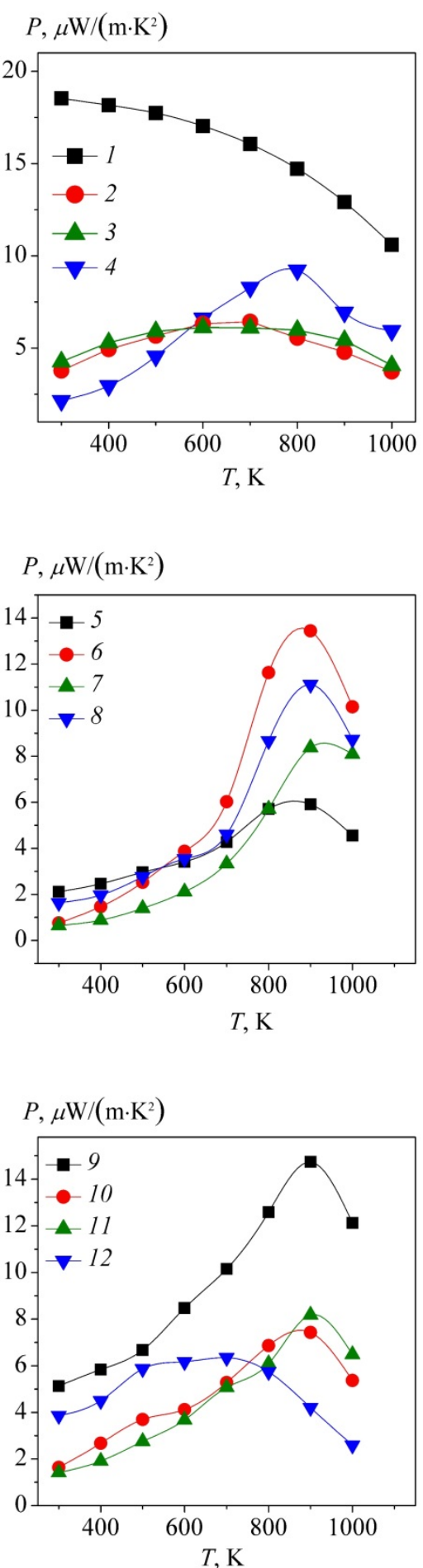

Figure 3. Temperature dependences of electrical conductivity $(\sigma)$, thermo-EMF coefficient $(S)$, and power factor $(P)$ of bismuth and AEM layered cobaltates: $1-\mathrm{Bi}_{2} \mathrm{Ca}_{2} \mathrm{Co}_{1.7} \mathrm{O}_{y}, 2-\mathrm{Bi}_{2} \mathrm{Ca}_{2} \mathrm{Co}_{1.6} \mathrm{Mn}_{0.1} \mathrm{O}_{y}, 3-\mathrm{Bi}_{2} \mathrm{Ca}_{2} \mathrm{Co}_{1.6} \mathrm{Zn}_{0.1} \mathrm{O}_{y}, 4-\mathrm{Bi}_{1.6} \mathrm{~Pb}_{0.4} \mathrm{Ca}_{2} \mathrm{Co}_{1.7} \mathrm{O}_{y} .5-\mathrm{Bi}_{2} \mathrm{Sr}_{2} \mathrm{Co}_{1.8} \mathrm{O}_{y}, 6-\mathrm{Bi}_{2} \mathrm{Sr}_{2} \mathrm{Co}_{1.7} \mathrm{Mn}_{0.1} \mathrm{O}_{y}, 7-$ $\mathrm{Bi}_{2} \mathrm{Sr}_{2} \mathrm{Co}_{1.7} \mathrm{Zn}_{0.1} \mathrm{O}_{y}, 8-\mathrm{Bi}_{1.6} \mathrm{~Pb}_{0.4} \mathrm{Sr}_{2} \mathrm{Co}_{1.8} \mathrm{O}_{y}, 9-\mathrm{Bi}_{2} \mathrm{Ba}_{2} \mathrm{Co}_{2} \mathrm{O}_{y}, 10-\mathrm{Bi}_{2} \mathrm{Ba}_{2} \mathrm{Co}_{1.9} \mathrm{Mn}_{0.1} \mathrm{O}_{y}, 11-\mathrm{Bi}_{2} \mathrm{Ba}_{2} \mathrm{Co}_{1.9} \mathrm{Zn}_{0.1} \mathrm{O}_{y}, 12-\mathrm{Bi}_{1.6} \mathrm{~Pb}_{0.4} \mathrm{Ba}_{2} \mathrm{Co}_{2} \mathrm{O}_{y}$. 
Table 3. Values of electrical conductivity $\left(\sigma_{T}\right)$, thermo-EMF coefficient $\left(S_{T}\right)$, and power factor $\left(P_{T}\right)$ of sintered ceramics based on of the bismuth and AEM layered cobaltates

\begin{tabular}{|c|c|c|c|c|c|c|}
\hline Compound & $\sigma_{300}, \mathrm{~S} / \mathrm{cm}$ & $S_{300}, \mu \mathrm{V} / \mathrm{K}$ & $P_{300}, \mu \mathrm{W} /\left(\mathrm{m} \cdot \mathrm{K}^{2}\right)$ & $\sigma_{1000}, \mathrm{~S} / \mathrm{cm}$ & $S_{1000}, \mu \mathrm{V} / \mathrm{K}$ & $P_{1000}, \mu \mathrm{W} /\left(\mathrm{m} \cdot \mathrm{K}^{2}\right)$ \\
\hline $\mathrm{Bi}_{2} \mathrm{Ca}_{2} \mathrm{Co}_{1,7} \mathrm{O}_{\mathrm{y}}$ & 8.21 & 150 & 18.5 & 7.32 & 120 & 10.6 \\
\hline $\mathrm{Bi}_{1,6} \mathrm{~Pb}_{0,4} \mathrm{Ca}_{2} \mathrm{Co}_{1,7} \mathrm{O}_{\mathrm{y}}$ & 1.66 & 114 & 2.15 & 3.72 & 126 & 5.94 \\
\hline $\mathrm{Bi}_{2} \mathrm{Ca}_{2} \mathrm{Co}_{1,6} \mathrm{Mn}_{0,1} \mathrm{O}_{\mathrm{y}}$ & 2.14 & 133 & 3.78 & 3.65 & 101 & 3.73 \\
\hline $\mathrm{Bi}_{2} \mathrm{Ca}_{2} \mathrm{Co}_{1,6} \mathrm{Zn}_{0,1} \mathrm{O}_{\mathrm{y}}$ & 2.66 & 127 & 4.27 & 4.07 & 100 & 4.07 \\
\hline $\mathrm{Bi}_{2} \mathrm{Sr}_{2} \mathrm{Co}_{1,8} \mathrm{O}_{\mathrm{y}}$ & 2.31 & 95.7 & 2.12 & 3.33 & 117 & 4.55 \\
\hline $\mathrm{Bi}_{1,6} \mathrm{~Pb}_{0,4} \mathrm{Sr}_{2} \mathrm{Co}_{1,8} \mathrm{O}_{\mathrm{y}}$ & 1.54 & 103 & 1.63 & 5.38 & 127 & 8.73 \\
\hline $\mathrm{Bi}_{2} \mathrm{Sr}_{2} \mathrm{Co}_{1,7} \mathrm{Mn}_{0,1} \mathrm{O}_{\mathrm{y}}$ & 1.19 & 80.0 & 0.76 & 3.92 & 161 & 10.1 \\
\hline $\mathrm{Bi}_{2} \mathrm{Sr}_{2} \mathrm{Co}_{1,7} \mathrm{Zn}_{0,1} \mathrm{O}_{\mathrm{y}}$ & 1.20 & 73.2 & 0.64 & 5.55 & 121 & 8.09 \\
\hline $\mathrm{Bi}_{2} \mathrm{Ba}_{2} \mathrm{Co}_{2} \mathrm{O}_{\mathrm{y}}$ & 10.9 & 68.6 & 5.13 & 9.46 & 113 & 12.1 \\
\hline $\mathrm{Bi}_{1.6} \mathrm{~Pb}_{0.4} \mathrm{Ba}_{2} \mathrm{Co}_{2} \mathrm{O}_{\mathrm{y}}$ & 8.55 & 67.2 & 3.86 & 9.80 & 51.5 & 2.60 \\
\hline $\mathrm{Bi}_{2} \mathrm{Ba}_{2} \mathrm{Co}_{1,9} \mathrm{Mn}_{0,1} \mathrm{O}_{\mathrm{y}}$ & 4.01 & 64.0 & 1.64 & 4.28 & 112 & 5.37 \\
\hline $\mathrm{Bi}_{2} \mathrm{Ba}_{2} \mathrm{Co}_{1,9} \mathrm{Zn}_{0,1} \mathrm{O}_{\mathrm{y}}$ & 5.67 & 50.0 & 1.42 & 6.99 & 96.3 & 6.48 \\
\hline
\end{tabular}

All the samples studied were $p$-type conductors, which conductivity character changed from semiconducting to metallic near 800-900 K (for $\mathrm{Bi}_{1.6} \mathrm{~Pb}_{0.4} \mathrm{Ba}_{2} \mathrm{Co}_{2} \mathrm{O}_{y}$ near $750 \mathrm{~K}$ ), except $\mathrm{Bi}_{2} \mathrm{Ca}_{2} \mathrm{Co}_{1.6} M_{0.1} \mathrm{Oy}(M=\mathrm{Mn}$. $\mathrm{Zn})$ solid solutions possessing semiconducting character of electrical conductivity within all temperature interval studied (Figure 3). Note that for the several samples $\left(\mathrm{Bi}_{1.6} \mathrm{~Pb}_{0.4} \mathrm{Ca}_{2} \mathrm{Co}_{1.7} \mathrm{O}_{y}\right.$, $\mathrm{Bi}_{2} \mathrm{Sr}_{2} \mathrm{Co}_{1.8} \mathrm{O}_{y}, \quad \mathrm{Bi}_{2} \mathrm{Sr}_{2} \mathrm{Co}_{1.7} \mathrm{Mn}_{0.1} \mathrm{O}_{y}, \quad \mathrm{Bi}_{2} \mathrm{Ba}_{2} \mathrm{Co}_{2} \mathrm{O}_{y}$, $\left.\mathrm{Bi}_{1.6} \mathrm{~Pb}_{0.4} \mathrm{Ba}_{2} \mathrm{Co}_{2} \mathrm{O}_{y}, \quad \mathrm{Bi}_{2} \mathrm{Ba}_{2} \mathrm{Co}_{1.9} M_{0.1} \mathrm{O}_{y} \quad(M=\mathrm{Mn}, \mathrm{Zn})\right)$ conductivity character changed again from metallic to semiconducting near 950-1000 K. Observed on the $\sigma=f(T)$ dependences anomalies were, probably, due to the evolution of so-called weakly-bonded oxygen from the samples to environment as well as due to the spin state transition of the cobalt ions in their crystal structure [10, 12].

Values of electrical conductivity of ceramics studied in this work (Figure 3, Table 3) were close to the literature data, according to them $\sigma$ of layered cobaltates of bismuth and AEE obtained using ceramic method varied within 2-20 $\mathrm{S} / \mathrm{cm}$ [14, 16-19]. So, for example electrical conductivity of $\mathrm{Bi}_{1.6} \mathrm{~Pb}_{0.4} \mathrm{Sr}_{2} \mathrm{Co}_{1.8} \mathrm{O}_{y}$ within 323-923 $\mathrm{K}$ temperature interval varied within $6-12 \mathrm{~S} / \mathrm{cm}[18]$ and $\sigma$ values of $\mathrm{Bi}_{1.5} \mathrm{~Pb}_{0.5} \mathrm{Ca}_{2}$ ${ }_{x} M_{x} \mathrm{Co}_{2} \mathrm{O}_{8-\delta}\left(M=\mathrm{Sc}^{3+}, \mathrm{Y}^{3+}\right.$, or $\left.\mathrm{La}^{3+}\right)$ ceramics at room temperature were less than $10 \mathrm{~S} / \mathrm{cm}$ [19]. Such values of electrical conductivity of ceramics are insufficiently large to use it in TEGs, but they can be improved using special methods of synthesis $[15,17]$ or sintering of ceramics [17] as well as by means of addition of noble metals powders (in particular, Ag) to the ceramics [18].

As can be seen from the Figure 3 and Table 3, electrical conductivity values of $\mathrm{Bi}_{2} \mathrm{Ca}_{2} \mathrm{Co}_{1.7} \mathrm{O}_{y}$ sharply decreased at substitution of $\mathrm{Bi}$ by $\mathrm{Pb}$ and of $\mathrm{Co}$ by $\mathrm{Mn}$ or $\mathrm{Zn}$ in its structure, for $\mathrm{Bi}_{2} \mathrm{Sr}_{2} \mathrm{Co}_{1.8} \mathrm{O}_{y}$ at such substitution the values of electrical conductivity at low temperatures decreased but at high temperatures increased, and, finally, electrical conductivity values of $\mathrm{Bi}_{2} \mathrm{Ba}_{2} \mathrm{Co}_{2} \mathrm{O}_{y}$ derivatives were smaller than for the parent phase, except $\mathrm{Bi}_{1.6} \mathrm{~Pb}_{0.4} \mathrm{Ba}_{2} \mathrm{Co}_{2} \mathrm{O}_{y}$ solid solution which $\sigma$ values within temperature intervals 500-800 and 1000-1100 $\mathrm{K}$ were larger than for
$\mathrm{Bi}_{2} \mathrm{Ba}_{2} \mathrm{Co}_{2} \mathrm{O}_{y}$ (Figure 3). Decreasing of electrical conductivity of derivatives of bismuth and AEE layered cobaltates in comparison to the parent complex oxides may be connected to the decreasing of mobilities of charge carriers ("holes") in them due to the creation of chemical inhomogeneity in the samples. Our data are in a good accordance with the results of [19] where had been found that partial substitution of calcium by lanthanum in $\mathrm{Bi}_{1.5} \mathrm{~Pb}_{0.5} \mathrm{Ca}_{2} \mathrm{Co}_{2} \mathrm{O}_{8-\delta}$ lead to the increasing of electrical resistivity of ceramics formed.

Maximal values of electrical conductivity $\mathrm{Bi}_{2} \mathrm{Ba}_{2} \mathrm{Co}_{2} \mathrm{O}_{y}$ and $\mathrm{Bi}_{1.6} \mathrm{~Pb}_{0.4} \mathrm{Ba}_{2} \mathrm{Co}_{2} \mathrm{O}_{y}$ cobaltates possessed (more than 10 $\mathrm{S} / \mathrm{cm}$ within temperature interval 500-900 K) (Figure 3).

Thermo-EMF coefficient values of the ceramic samples studied increased (for $\mathrm{Bi}_{2} \mathrm{Ca}_{2} \mathrm{Co}_{1.7} \mathrm{O}_{y}$, in contrast, decreased) at temperature increasing, hereby and for the almost all samples at relatively high temperatures (for example, above $600 \mathrm{~K}$ for $\mathrm{Bi}_{2} \mathrm{Ca}_{2} \mathrm{Co}_{1.6} \mathrm{Mn}_{0.1} \mathrm{O}_{y}$, and above $900 \mathrm{~K}$ for $\mathrm{Bi}_{2} \mathrm{Sr}_{2} \mathrm{Co}_{1.8} \mathrm{O}_{y}$ ) values of thermo-EMF coefficient decreased at temperature increasing (Figure 3). Observed anomalies of thermo-EMF of the layered cobaltates as anomalies of their electrical conductivity are, obviously, due to change of their oxygen stoichiometry and spin state of cobalt ions in their crystal structure.

Values of the thermo-EMF coefficient of the samples studied in this work varied, in the whole, within 100-150 $\mu \mathrm{V} / \mathrm{K}$ and were typical for the layered cobaltates of the bismuth and AEE and their derivatives [12-14, 16-18]. Maximal values of Seebeck's coeficient were found for $\mathrm{Bi}_{2} \mathrm{Sr}_{2} \mathrm{Co}_{1.7} \mathrm{Mn}_{0.1} \mathrm{O}_{y}$ solid solution (about $160 \mu \mathrm{V} / \mathrm{K}$ within temperature interval 900-100 K) (Table 3).

Power factor values of $\mathrm{Bi}_{2} \mathrm{Ca}_{2} \mathrm{Co}_{1.7} \mathrm{O}_{y}$ decreased at temperature increasing, and for all other samples nonmonotonously changed when temperature increased and had passed through maximum near 800-900 K depending on composition (Figure 3). Such maxima on the $P=f(T)$ dependences for the cobaltates studied is connected with the maxima on their $\sigma=f(T)$ and $S=f(T)$ dependences (see above) (Figure 3). At $1000 \mathrm{~K}$ power factor reaches maximal 
values for $\mathrm{Bi}_{2} \mathrm{Ba}_{2} \mathrm{Co}_{2} \mathrm{O}_{y}, \quad \mathrm{Bi}_{2} \mathrm{Sr}_{2} \mathrm{Co}_{1.7} \mathrm{Mn}_{0.1} \mathrm{O}_{y}$, and $\mathrm{Bi}_{2} \mathrm{Ca}_{2} \mathrm{Co}_{1.7} \mathrm{O}_{y}$ compounds - 12.1, 10.1, and $10.6 \mu \mathrm{W} /\left(\mathrm{m} \cdot \mathrm{K}^{2}\right)$ respectively (Table 3 ), but within all the temperature interval studied the maximal values power factor are found for $\mathrm{Bi}_{2} \mathrm{Ca}_{2} \mathrm{Co}_{1.7} \mathrm{O}_{y}, \quad \mathrm{Bi}_{2} \mathrm{Sr}_{2} \mathrm{Co}_{1.7} \mathrm{Mn}_{0.1} \mathrm{O}_{y}$, and $\mathrm{Bi}_{2} \mathrm{Ba}_{2} \mathrm{Co}_{2} \mathrm{O}_{y}$ cobaltates $-18.5,13.5$, and $14,7 \mu \mathrm{W} /\left(\mathrm{m} \cdot \mathrm{K}^{2}\right)$ at temperatures 300,900 , and $900 \mathrm{~K}$ respectively.

Values of power factor of ceramics based on the layered cobaltates of bismuth and AEE obtained in this work are less than ones for ceramics based on the layered cobaltates of sodium and calcium [5, 9-12] but they can be improved by means of enlarging of electrical conductivity of ceramics using different ways (see above).

It is note two features of ceramics based on the layered cobaltates of bismuth and AEE which distinguish them from ceramics based on the layered cobaltates of sodium $\left(\mathrm{Na}_{x} \mathrm{CoO}_{2}\right)$ or calcium $\left(\mathrm{Ca}_{3} \mathrm{Co}_{4} \mathrm{O}_{9+\delta}\right)$ : relatively large values of power factor near the room temperature and weak dependence of power factor on temperature. The first feature indicates the possibility of usage of this ceramics in TEGs operating near the room temperature, the second demonstrates its good self-compatibility within wide interval of temperatures.

\section{Conclusions}

By means of solid-state reactions method the ceramic samples of $(\mathrm{Bi}, \mathrm{Pb})_{2} \mathrm{Ba}_{2}(\mathrm{Co}, M)_{2} \mathrm{O}_{y},(\mathrm{Bi}, \mathrm{Pb})_{2} \mathrm{Sr}_{2}(\mathrm{Co}, M)_{1.8} \mathrm{O}_{y}$, and $(\mathrm{Bi}, \mathrm{Pb})_{2} \mathrm{Ca}_{2}(\mathrm{Co}, M)_{1.7} \mathrm{O}_{y}(M=\mathrm{Mn}, \mathrm{Zn})$ solid solutions had been prepared, their crystal structure, thermal expansion, electrical conductivity, thermo-EMF, and power factor were investigated. The effect of the bismuth substitution by lead and cobalt substitution by manganese and zinc in the $\mathrm{Bi}_{2} \mathrm{Ba}_{2} \mathrm{Co}_{2} \mathrm{O}_{y}, \mathrm{Bi}_{2} \mathrm{Sr}_{2} \mathrm{Co}_{1.8} \mathrm{O}_{y}$, and $\mathrm{Bi}_{2} \mathrm{Ca}_{2} \mathrm{Co}_{1.7} \mathrm{O}_{y}$ layered cobaltates on the crystal structure, physicochemical, and functional properties of their derivatives was discussed. It was determined that cobaltates studied are the $p$-type conductors, which linear thermal expansion coefficient (LTEC) values varied within (9.68-13.2) $10^{-6} \mathrm{~K}^{-1}$.

It was found that at $1000 \mathrm{~K}$ power factor reached maximal values for $\mathrm{Bi}_{2} \mathrm{Ba}_{2} \mathrm{Co}_{2} \mathrm{O}_{y}, \quad \mathrm{Bi}_{2} \mathrm{Sr}_{2} \mathrm{Co}_{1.7} \mathrm{Mn}_{0.1} \mathrm{O}_{y}$, and $\mathrm{Bi}_{2} \mathrm{Ca}_{2} \mathrm{Co}_{1.7} \mathrm{O}_{y}$ compounds - 12.1, 10.1, and $10.6 \mu \mathrm{W} /\left(\mathrm{m} \cdot \mathrm{K}^{2}\right)$ respectively, but within all the temperature interval studied the maximal values power factor were observed for $\mathrm{Bi}_{2} \mathrm{Ca}_{2} \mathrm{Co}_{1.7} \mathrm{O}_{y}, \quad \mathrm{Bi}_{2} \mathrm{Sr}_{2} \mathrm{Co}_{1.7} \mathrm{Mn}_{0.1} \mathrm{O}_{y}$, and $\mathrm{Bi}_{2} \mathrm{Ba}_{2} \mathrm{Co}_{2} \mathrm{O}_{y}$ cobaltates $-18.5,13.5$, and $14,7 \mu \mathrm{W} /\left(\mathrm{m} \cdot \mathrm{K}^{2}\right)$ at temperatures 300,900 , and $900 \mathrm{~K}$ respectively.

It was also detected that partial substitution of bismuth by lead and of cobalt by manganese or zinc in $\mathrm{Bi}_{2} \mathrm{Sr}_{2} \mathrm{Co}_{1.8} \mathrm{O}_{y}$ layered cobaltate let us essentially increase the functional (thermoelectric) properties of its derivatives. So power factor values of $\mathrm{Bi}_{2} \mathrm{Sr}_{2} \mathrm{Co}_{1.7} \mathrm{Mn}_{0.1} \mathrm{O}_{y}, \mathrm{Bi}_{2} \mathrm{Sr}_{2} \mathrm{Co}_{1.7} \mathrm{Zn}_{0.1} \mathrm{O}_{y}$, and $\mathrm{Bi}_{1.6} \mathrm{~Pb}_{0.4} \mathrm{Sr}_{2} \mathrm{Co}_{1.8} \mathrm{O}_{y}$ solid solutions at $900 \mathrm{~K}$ are 2.3, 1.4, and 1.9 times higher than for $\mathrm{Bi}_{2} \mathrm{Sr}_{2} \mathrm{Co}_{1.8} \mathrm{O}_{y}$ parent phase.

\section{Abbreviations}

EMF electromotive force

AEM alkaline-earth metals

XRD x-ray diffraction

LTEC linear thermal expansion coefficient

TEG thermoelectrogenerator

\section{Acknowledgements}

This work was carried out in the frame of SPSI «Physical materials science, new materials and technologies» (subprogram «Materials science and materials technologies», task 1.26).

\section{REFERENCES}

[1] T.M. Tritt, M.A. Subramanian, H. Botner, T. Caillat, G. Chen, R. Funahashi, X. Ji, M. Kanatzidis, K. Koumoto, G.S. Nolas, J. Poon, A.M. Rao, I. Terasaki, R. Venkatasubramanian, J. Yang, Special issue on harvesting energy through thermoelectrics: Poer generation and cooling, MRS Bull., Vol. 31, 2006.

[2] K. Koumoto, I. Terasaki, N. Murayama (eds.). Oxide Thermoelectrics. Research Signpost, Trivandrum, India, Research Signpost, 2002.

[3] J. He, Y. Liu, Oxide thermoelectrics: The challnges, progress, and outlook, J. Mater. Res., Vol. 26, No. 15, 1762-1772, 2011.

[4] K. Koumoto, R. Funahashi, E. Guilmeau, Y. Miyazaki, A. Weidenkaff, Y. Wang, C. Wan, Thermoelectric Ceramics for Energy Harvesting, J. Am. Ceram. Soc., Vol. 96, No. 1, 1-23, 2013.

[5] C.-H. Lim, S.-M. Choi, W.-S. Seo, H.-H. Park, A Power-Generation Test for Oxide-Based Thermoelectric Modules Using $p$-Type $\mathrm{Ca}_{3} \mathrm{Co}_{4} \mathrm{O}_{9}$ and $n$-Type $\mathrm{Ca}_{0.9} \mathrm{Nd}_{0.1} \mathrm{MnO}_{3}$ Legs, J. Electron. Mater., Vol. 41, No. 6, 1247-1255, 2012.

[6] J. Liu, H.C. Wang, W.B. Su, C.L. Wang, J.L. Zhang, L.M. Mei, Synthesis and thermoelectric properties of $\mathrm{Sr}_{0.95} \mathrm{La}_{0.05} \mathrm{TiO}_{3-\delta}-$ $\mathrm{TiO}_{2}$ solid solutions, Solid State Sciences, Vol. 12, 134-137, 2010.

[7] M. Yasukawa, N. Murayama, A promising oxide material for high-temperature thermoelectric energy conversion: $\mathrm{Ba}_{1-}$ ${ }_{x} \mathrm{Sr}_{\mathrm{x}} \mathrm{PbO}_{3}$ solid solution system, Mat. Sci. \& Eng. B, Vol. 54, 64-69, 1998.

[8] E. A. Chizhova, A. I. Klyndyuk, Synthesis and Thermoelectric Properties of Ceramics Based on Barium-Strontium Metaplumbates, Glass Phys. Chem., Vol. 39, No. 4, 453-457, 2013.

[9] M. Lee, L. Viciu, L. Li, Y. Wang, M. L. Foo, S. Watauchi, R. A. Pascal Jr., R. J. Cava, N. P. Ong, Large enhancement of the thermopower in $\mathrm{Na}_{\mathrm{x}} \mathrm{CoO}_{2}$ at high $\mathrm{Na}$ doping, Nature Materials, Vol. 5, 537-540, 2006. 
[10] N.S. Krasutskaya, A.I. Klyndyuk, L.E. Evseeva, S.A. Tanaeva, Synthesis and Properties of $\mathrm{Na}_{x} \mathrm{CoO}_{2}(x=0.55,0.89)$ Oxide Thermoelectrics, Inorg. Mater. Vol. 52, No. 4, 393-399, 2016.

[11] J. Xu, C. Wei, K. Jia, Thermoelectric performance of textured $\mathrm{Ca}_{3-x} \mathrm{Yb}_{x} \mathrm{Co}_{4} \mathrm{O}_{9-\delta}$ ceramics, J. of Alloys and Comp. Vol. 500, 227-230, 2010.

[12] I.V. Matsukevich, A.I. Klyndyuk, E.A. Tugova, M.V. Tomkovich, N.S. Krasutskaya, V.V. Gusarov, Synthesis and Properties of Materials Based on Layered Calcium and Bismuth Cobaltites, Rus. J. Appl. Chem. Vol. 88, Iss. 8, 12411247, 2015.

[13] M. Hervieu, A. Maignan, C. Michel, V. Hardy, N. Creon, B. Raveau, Metallicity and thermopower of the misfit cobaltite $\left[\mathrm{Bi}_{2} \mathrm{Ba}_{1.8} \mathrm{Co}_{0.2} \mathrm{O}_{4}\right]^{\mathrm{RS}}\left[\mathrm{CoO}_{2}\right]_{2}$, Phys. Rev. B, Vol. 67, 045112, 2003.

[14] M. Kato, Y. Goto, K. Umehara, K. Hirota, K. Yoshimura, Synthesis and physical properties of $\mathrm{Bi}-\mathrm{Sr}-\mathrm{Co}$-oxides with 2D-triangular Co layers intercalated by iodine, Physica B, Vol. 378-380, 1062-1063, 2006.

[15] H. Muguerra, B. Rivas-Murias, M. Traianidis, C. Henrist, B.
Vertruyen, R. Cloots, Improvement of the thermoelectric properties of $\left[\mathrm{Bi}_{1.68} \mathrm{Ca}_{2} \mathrm{O}_{4-\delta}\right]^{\mathrm{RS}}\left[\mathrm{CoO}_{2}\right]_{1.69}$ cobaltite by chimie duce methods, J. Solid State Chem., Vol.183, 1252-1257, 2010.

[16] Y. Tanaka, T. Fujii, M. Nakanishi, Y. Kusano, H. Hashimoto, Y. Ikeda, J. Takada, Systematic study on synthesis and structural, electrical transport and magnetic properties of Pb-substituted Bi-Ca-Co-O misfit-layer cobaltites, Solid State Commun., Vol. 141, 122-126, 2007.

[17] A. Sotelo, Sh. Rasekh, M.A. Madre, E. Guilmeau, S. Marinel, J.C. Diez, Solution-based synthesis routes to thermoelectric $\mathrm{Bi}_{2} \mathrm{Ca}_{2} \mathrm{Co}_{1.7} \mathrm{O}_{\mathrm{x}}$, J. Eur. Ceram. Soc. Vol. 31, 1763-1769, 2011.

[18] J.C. Diez, Sh. Rasekh, G. Constantinescu, M.A. Torres, M.A. Madre, A. Sotelo, Effect of Ag additions on the $\mathrm{Bi}_{1.6} \mathrm{Sr}_{2} \mathrm{Co}_{1.8} \mathrm{O}_{x}$ thermoelectric properties, Bol. Soc. Esp. Ceram. Vidr., Vol 52, No. 2, 93-97, 2013.

[19] E. Iguchi, S. Katoh, H. Nakatsugawa, F. Munakata, Thermoelectric Properties (Resistivity and Thermopower) in $\mathrm{Bi}_{1.5} \mathrm{~Pb}_{0.5} \mathrm{Ca}_{2-\chi} M_{x} \mathrm{Co}_{2} \mathrm{O}_{8-\delta}\left(M=\mathrm{Sc}^{3+}, \mathrm{Y}^{3+}\right.$, or $\left.\mathrm{La}^{3+}\right)$, J. Solid State Chem., Vol. 167, 472-479, 2002. 